\title{
Ziziphus mauritiana (Jujube) Seed as a Protein Source in the Diet Promote Growth Performance and Stabilized Hematology, Lipid Profile and Serum Chemistry Profile of Rattus norvergicus
}

\author{
Adenike R. Alawode ${ }^{1^{*}}$, Ahmed Y. lyaka ${ }^{2}$, Muhammed M. Ndamitso ${ }^{2}$, Julian C. Anuonye ${ }^{3}$ \\ ${ }^{1}$ Forestry research institute of Nigeria-Southern Guinea Research Station, Mokwa, Niger State, Nigeria \\ ${ }^{2}$ Department OF Chemistry, Federal University OF Technology, Minna, P.M.B. 65, Niger State, Nigeria \\ ${ }^{3}$ Department of Food Science and Technology, Federal University oF Technology, Minna, P.M.B. 65, \\ Niger State, Nigeria
}

\begin{abstract}
The increase search for easily available and cheaper alternative sources of proteins to meet up the increase protein demand necessitated the present study which was design to assess the effects of graded levels of jujube (Ziziphus mauritiana) seed inclusion in the diets of weaners rats. Twenty-five weaner rats were allocated into five groups of formulated diet consisting of treatment 1 - 5 in which soya bean was replaced with Ziziphus mauritiana seed at $0 \%$ (control), $25 \%, 50 \%, 75 \%$, and $100 \%$ respectively for 3 weeks. Effects of the diets on lipid profile, haematology and serum chemistry were evaluated. Rats fed $25 \%, 50 \%$ and $100 \%$ Z. mauritiana had significantly higher feed intake and weight gain when compared with the normal control. All levels of inclusion tested increases the concentrations of serum total proteins and bilirubin but decreases the cholesterol and platelet counts when compared with the control. No diet related alterations were recorded for the relative organ's ratio, aspartate transaminase, alanine transaminase, albumins, urea, creatinine, sodium, chloride, high- and low-density lipoprotein, triglyceride and hematological indices analyzed. However, seed inclusion only at $100 \%$ significantly $(p<0.05)$ increases the total white blood cell count and relative liver weight ratio. Ziziphus mauritiana seed possess good dietary protein quality for optimal growth of rats and does not elicit any adverse effect on haematological and serum biochemical indices of organs integrity.
\end{abstract}

Key words: Ziziphus mauritiana, hematology, lipid profile, serum chemistry, diet.

\section{Introduction}

Malnutrition is one of the main causes of high infant mortality in developing countries especially in sub-saharan Africa [1]. According to WHO [2], about $30 \%$ of the global population are malnourished resulting in about daily mortality of 40,000 children [2]. Self-sufficiency in food production in order to equilibrate food demand with supply and reduced malnutrition is one of the main goals of both state and federal government of Nigeria [3].

\footnotetext{
* Corresponding author: Alawode R. Adenike, rahmatalahadenike@gmail.com

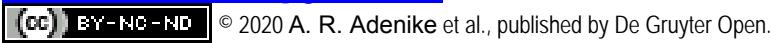
This work was licensed under the Creative Commons Attribution-NonCommercialNoDerivs 3.0 License
}

The consumption of animal protein sources in developing countries is ever increasing, however, the demand for animal protein sources in Nigeria is higher than the supply [4]. This has strongly obliged the necessity to explore easily available and cheaper alternative sources of proteins as a means of alleviating the overwhelming shortage of animal protein [5].

Ziziphus mauritiana Lam (family; Rhamnaceae) also known as Jujube is a tropical fruit tree that grows in arid and semiarid regions of the tropics [6], the plant is also called magarya by traditional herbalist of northern Nigeria [7] where it is commonly used for the treatment of convulsion, epilepsy, diarrhea, sexual disability, ulcers, digestive and urinary discomfort, cough, fever, sleep disorders, obesity, burning sensations, 
fever, skin disease, wound, ulcers and stomatitis [8]. Various parts of Ziziphus mauritiana have also been reported for immunomodulatory [9], antioxidant [10], anticancer [11], anti-diarrhoeal [12] hypoglycemic, hypolipidemic [13], antiulcer [14], antimicrobial [15], and antiplasmodial [16] activities.

However, despite the medicinal properties of Ziziphus mauritiana, its seed is less explored, underutilized and are often discarded as a waste. However, recent studies have indicated that the less underutilized seed could serve as a rich source of nutrient thus contribute to solving the problems of malnutrition. To this end the present study investigated the effect of replacements of dietary proteins with Ziziphus mauritiana seed on growth performance, hematology, lipid profile ad serum chemistry of albino rats.

\section{Material and Methods}

Sample collections

Matured fruits of Ziziphus mauritiana fruits were were picked directly from the trees in March, 2017 from Barnawa area of Kaduna, Kaduna State. The sample was identified and authenticated at the herbarium unit of Department of Biological Sciences Ahmadu Bello University where existing voucher number of the specimen (No. 7072) was given.

Chemicals and Reagent

Biochemical assay kits including, AST, ALT, ALP, Total proteins, albumin, urea and creatinine were product of Randox Liquizyme assay kits. Total cholesterol, triglycerides and high-density lipoprotein (HDL)-cholesterol kits were product of agape diagnostic Itd.

\section{Experimental animals}

Twenty-five (25) weaners rats weighing $60 \pm 5.45 \mathrm{~g}$ (4-5 weeks old) were obtained from Animal Holding Unit, School of life science, Federal University of Technology, Minna, Nigeria. Animals were kept and used in compliance with internationally accepted principles for human handling and use of laboratory animals as contained in the Canadian council on Animal Care Guidelines and Protocol Review.

Sample preparation

The fruits were macerated in water to remove the pulp and the seeds were rinsed in clean water. Thereafter the seeds were spread out and sun dried. The dried seeds were grounded and sieved through a mesh to obtain a fine powder which was stored in air tight container.

Experimental design and treatments

Five diets were formulated consisting of 5 treatments (A-E) in which soya bean was replaced with Ziziphus mauritiana seed at 0\%, 25\%, 50\%, $75 \%$, and $100 \%$ respectively as shown in Table 1 . The animals were fed once (9;00 am) daily and water was given ad libidum. The amount of feed taken by the individual rats was estimated daily by deducting the left-over feed from the daily feed given.

\section{Nutrient formulation}

Table 1.

\begin{tabular}{l|c|c|c|c|c}
\hline Ingredients (\%) & A & B & C & D & E \\
\hline Maize & 450 & 450 & 450 & 450 & 450 \\
Maize offal & 350 & 350 & 350 & 350 & 350 \\
Soya beans & 100 & 75 & 50 & 25 & 00 \\
Z. mauritiana & 0 & 25 & 50 & 75 & 100 \\
Palm kernel cake & 40 & 40 & 40 & 40 & 40 \\
Bone meal & 20 & 20 & 20 & 20 & 20 \\
Minerals & 7.5 & 7.5 & 7.5 & 7.5 & 7.5 \\
Methionine & 2.5 & 2.5 & 2.5 & 2.5 & 2.5 \\
Lysine & 2.5 & 2.5 & 2.5 & 2.5 & 2.5 \\
Vitamins & 25 & 25 & 25 & 25 & 25 \\
Salt & 2.5 & 2.5 & 2.5 & 2.5 & 2.5 \\
\hline
\end{tabular}

Blood collection and Serum Preparation

After 21 days of feeding trial, the animals were sacrificed under ether anaesthesia and blood was collected in EDTA bottle for haematological analysis. Another set of blood was collected in
EDTA free sample bottle, the blood was allowed to cloth and centrifuge at $3000 \mathrm{rpm}$ for 10 minutes [17-18]. The plasma samples were collected and kept in a freezer $\left(-20^{\circ} \mathrm{C}\right)$ until needed for biochemical analyses. 
Analysis of Biochemical and Haematology Parameters

The estimation of biochemical parameters including transaminases [19] total protein [20], albumin and bilirubim [21], urea, creatinine and electrolyte concentrations from serum were assayed using standard protocols [22]. Serum concentrations of lipid profile including total cholesterol, triglycerides and high density lipoprotein (HDL)-cholesterol were assay by enzymatic colorimetric methods using commercial kits according to the manufacturer's instructions. VLDL-cholesterol was estimated as $\mathrm{TG} / 5$, and LDL-cholesterol was calculated using Friedewald formula [23] as follows:

$\operatorname{LDL}(\mathrm{mg} / \mathrm{dl})=\mathrm{TC}-(\mathrm{HDL}+\mathrm{VLDL})$

The hematological components including hemoglobin $(\mathrm{Hb})$, packed cell volume (PCV), red blood cells (RBC), white blood cells (WBC) and platelet count (PLT) were determined using the automated hematologic analyzer SYSMEX KX21, a product of SYSMEX Corporation, Japan employing the methods described by Dacie and Lewis [24].

Statistical Analysis

Statistical analysis system was used for data analysis. Mean \pm SD were presented for each analysis while one-way analysis of variance and Duncan's Multiple Range Test were used for group comparison at $p<0.05$ significance

\section{Results}

Feed intake and Weight gain

After three (3) weeks of feeding trials rats fed $75 \%$ Z. mauritiana proteins had the least feed intake $(127.15 \pm 0.78 \mathrm{~g})$ comparable with the normal control $(121.70 \pm 0.71 \mathrm{~g})$, rats fed $25 \%, 50 \%$ and $100 \%$ Z. mauritiana had significantly higher feed intake of $157.70 \pm 5.09 \mathrm{~g}, \quad 150.35 \pm 0.71 \mathrm{~g}$ and $145.45 \pm 0.92 \mathrm{~g}$ respectively (Table 2 ). Rats fed $50 \%$ and $100 \%$ Z. mauritiana proteins had the highest weight gain of $27.50 \pm 0.00 \mathrm{~g}$ and $28.50 \pm 4.92 \mathrm{~g}$ respectively when compared with the normal control (Table 3).

Table 2.

Weekly feed Intake of rats fed graded level of Z. mauritiana as protein source

\begin{tabular}{rccc}
\hline Feed & Week1 & Week2 & Week3 \\
\hline $0 \%$ & $148.75 \pm 0.35^{\mathrm{d}}$ & $132.85 \pm 0.35^{\mathrm{c}}$ & $121.70 \pm 0.71^{\mathrm{a}}$ \\
$25 \%$ & $121.85 \pm 0.71^{\mathrm{b}}$ & $182.45 \pm 1.06^{\mathrm{d}}$ & $157.70 \pm 5.09^{\mathrm{c}}$ \\
$50 \%$ & $92.65 \pm 0.71^{\mathrm{a}}$ & $152.05 \pm 0.71^{\mathrm{b}}$ & $150.35 \pm 0.71^{\mathrm{c}}$ \\
$75 \%$ & $139.90 \pm 5.52^{\mathrm{c}}$ & $122.55 \pm 2.90^{\mathrm{a}}$ & $127.15 \pm 0.78^{\mathrm{a}}$ \\
$100 \%$ & $184.90 \pm 1.56^{\mathrm{e}}$ & $147.00 \pm 1.13^{\mathrm{b}}$ & $145.45 \pm 0.92^{\mathrm{b}}$ \\
\hline
\end{tabular}

Data are Mean $\pm S D$ of triplicate determination. Data followed by different superscript alphabet in each column are significantly different $(p<0.05)$

Table 3.

Weight changes of rats fed graded level of $Z$. mauritiana as protein source

\begin{tabular}{llll}
\hline $\begin{array}{c}\text { Feed } \\
\text { \% }\end{array}$ & \multicolumn{1}{c}{ Initial } & \multicolumn{1}{c}{ Final } & Weight gain \\
\hline 0 & $64.50 \pm 17.68$ & $82.50 \pm 30.41$ & $18.00 \pm 24.40^{\mathrm{a}}$ \\
25 & $80.00 \pm 1.41$ & $96.50 \pm 3.54$ & $16.50 \pm 3.18^{\mathrm{a}}$ \\
50 & $88.00 \pm 0.00$ & $115.50 \pm 0.00$ & $27.50 \pm 0.00^{\mathrm{b}}$ \\
75 & $94.50 \pm 34.65$ & $115.00 \pm 12.75$ & $20.50 \pm 1.92^{\mathrm{a}}$ \\
100 & $88.50 \pm 12.02$ & $97.00 \pm 9.89$ & $28.50 \pm 4.92^{\mathrm{b}}$ \\
\hline
\end{tabular}

Data are Mean $\pm S D$ of triplicate determination. Data followed by different superscript alphabet in each column are significantly different $(p<0.05)$

Relative organs body weight

The relative organs body weight of the animal's kidney, lung, hear and spleen were not significantly $(p>0.05)$ different from the control values. However, the relative liver body weight ratio was significantly $(p<0.05)$ higher in rats fed $100 \%$ Z. mauritiana protein when compared with the control and other experimental groups (Table 4).

Table 4.

\section{Relative organ weight $(\mathrm{g})$ ratio of rat fed graded level of $Z$. mauritiana as protein source}

\begin{tabular}{cccccc}
\hline Feed & Liver & Kidney & Lung & Heart & Spleen \\
\hline $0 \%$ & $0.025 \pm 0.19^{\mathrm{a}}$ & $0.005 \pm 0.00^{\mathrm{a}}$ & $0.014 \pm 0.00^{\mathrm{a}}$ & $0.003 \pm 0.00^{\mathrm{a}}$ & $0.003 \pm 0.00^{\mathrm{a}}$ \\
$25 \%$ & $0.028 \pm 0.00^{\mathrm{a}}$ & $0.005 \pm 0.00^{\mathrm{a}}$ & $0.010 \pm 0.00^{\mathrm{a}}$ & $0.004 \pm 0.00^{\mathrm{a}}$ & $0.004 \pm 0.00^{\mathrm{a}}$ \\
$50 \%$ & $0.021 \pm 0.01^{\mathrm{a}}$ & $0.006 \pm 0.00^{\mathrm{a}}$ & $0.014 \pm 0.00^{\mathrm{a}}$ & $0.004 \pm 0.00^{\mathrm{a}}$ & $0.003 \pm 0.00^{\mathrm{a}}$ \\
$75 \%$ & $0.027 \pm 0.28^{\mathrm{a}}$ & $0.005 \pm 0.00^{\mathrm{a}}$ & $0.012 \pm 0.00^{\mathrm{a}}$ & $0.004 \pm 0.00^{\mathrm{a}}$ & $0.003 \pm 0.00^{\mathrm{a}}$ \\
$100 \%$ & $0.045 \pm 0.00^{\mathrm{b}}$ & $0.005 \pm 0.00^{\mathrm{a}}$ & $0.012 \pm 0.00^{\mathrm{a}}$ & $0.004 \pm 0.00^{\mathrm{a}}$ & $0.003 \pm 0.00^{\mathrm{a}}$
\end{tabular}

Data are Mean \pm SD of triplicate determination. Data followed by different superscript alphabet are significantly different $(p<0.05)$. 


\section{Biochemical}

The serum activities of aspartate transaminase, alanine transaminase (figure 1) and the concentrations of albumins (figure 2), urea (figure
3), creatinine (figure 4), sodium and chloride (figure 5 ) in rats fed $25 \%, 50 \%, 75 \%$ and $100 \% Z$. mauritiana proteins were not significantly $(p>0.05)$ different from the control values.

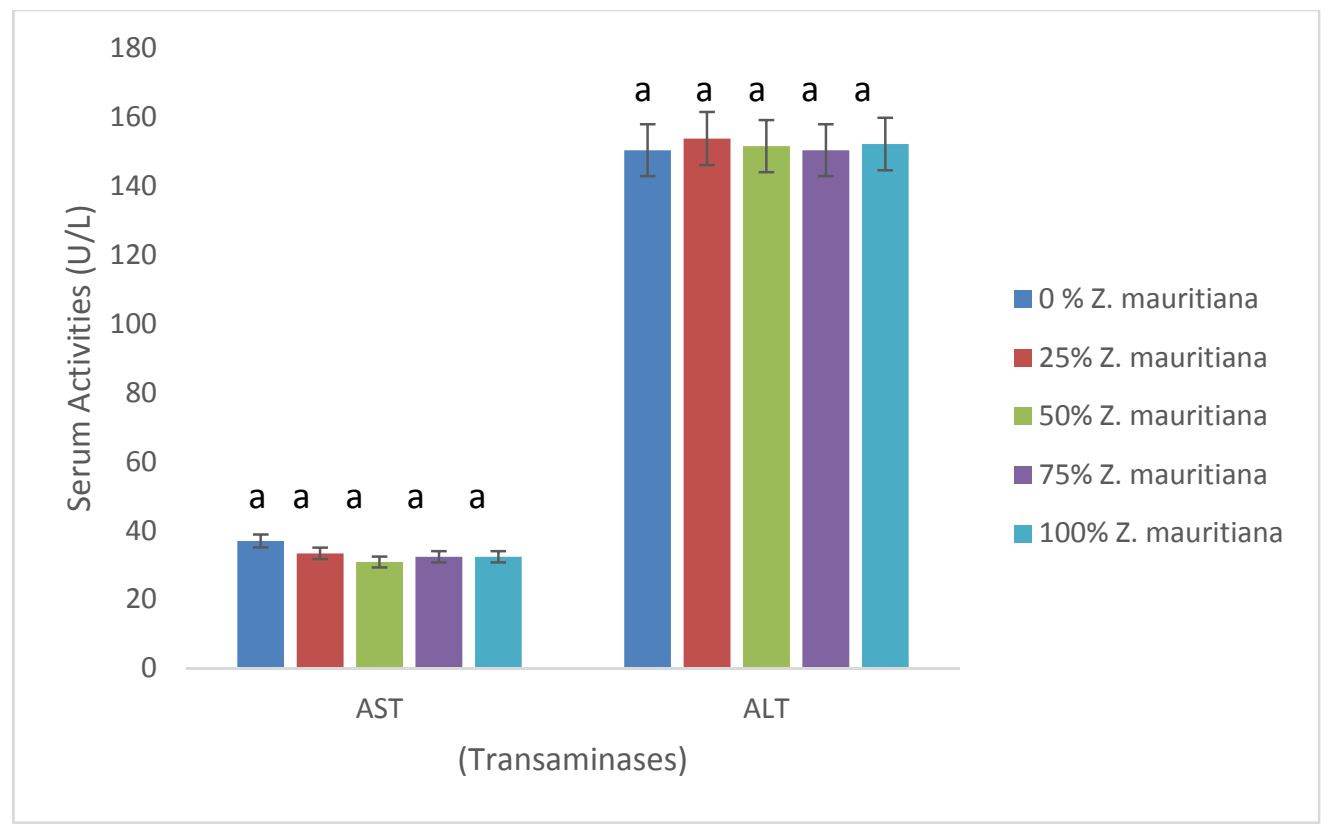

Figure 1. Effect of graded level of $Z$. mauritiana inclusion as protein source on transaminase activities in rats

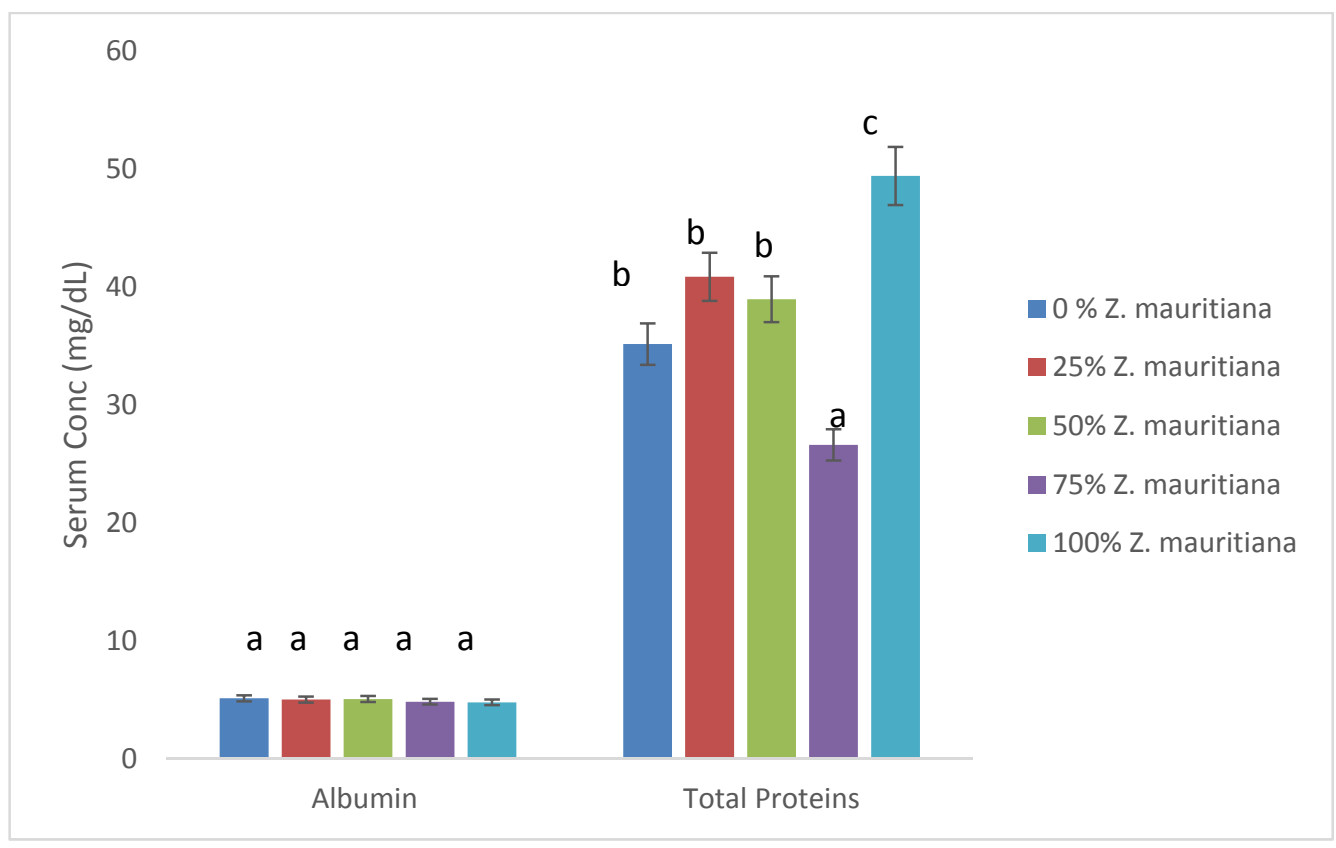

Figure 2. Effect of graded level of $Z$. mauritiana inclusion as protein source on albumin and total proteins concentration in rats 


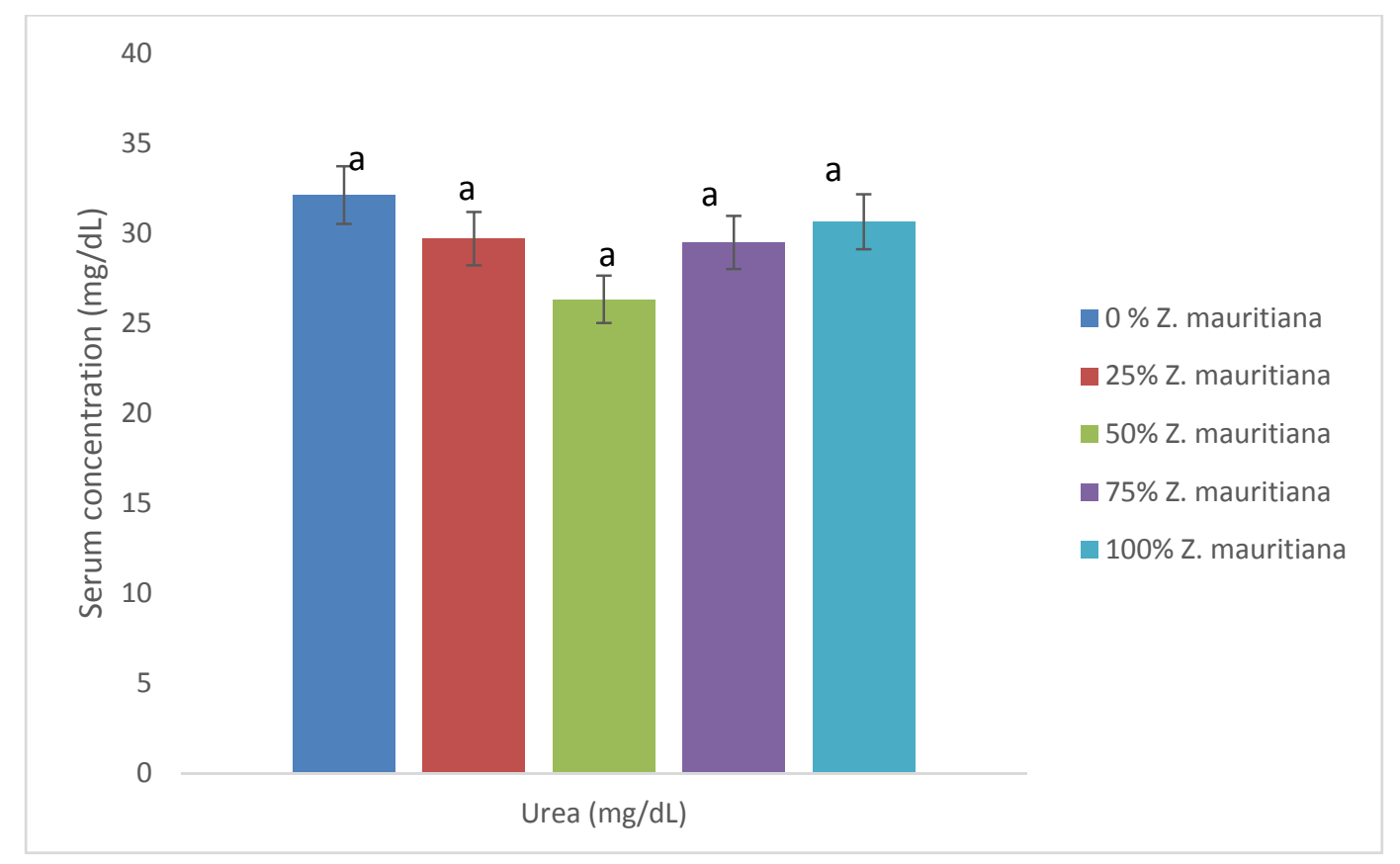

Figure 3. Effect of graded level of $Z$. mauritiana inclusion as protein source on urea concentration in rats

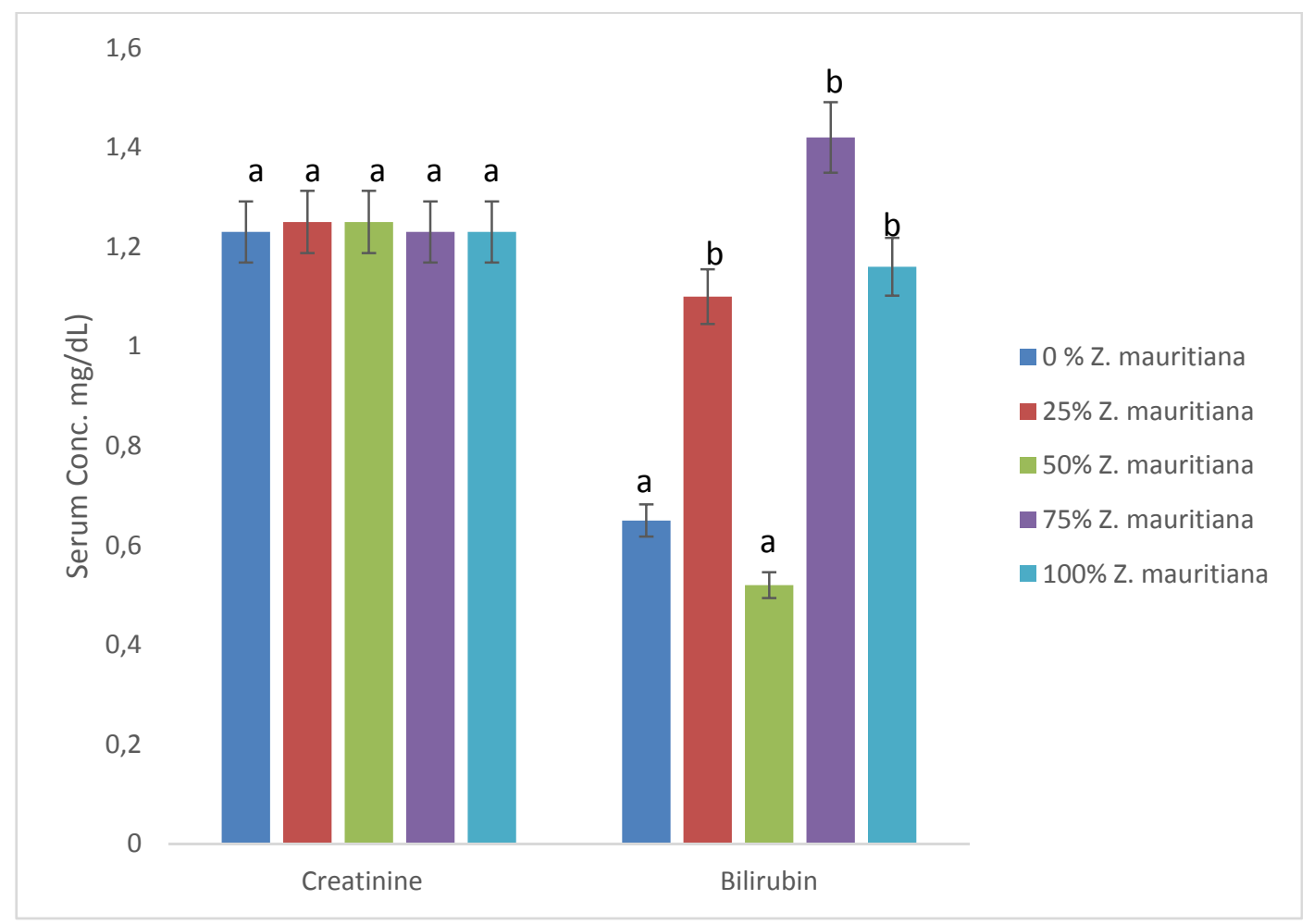

Figure 4. Effect of graded level of $Z$. mauritiana inclusion as protein source on creatinine and bilirubin concentrations in rats 


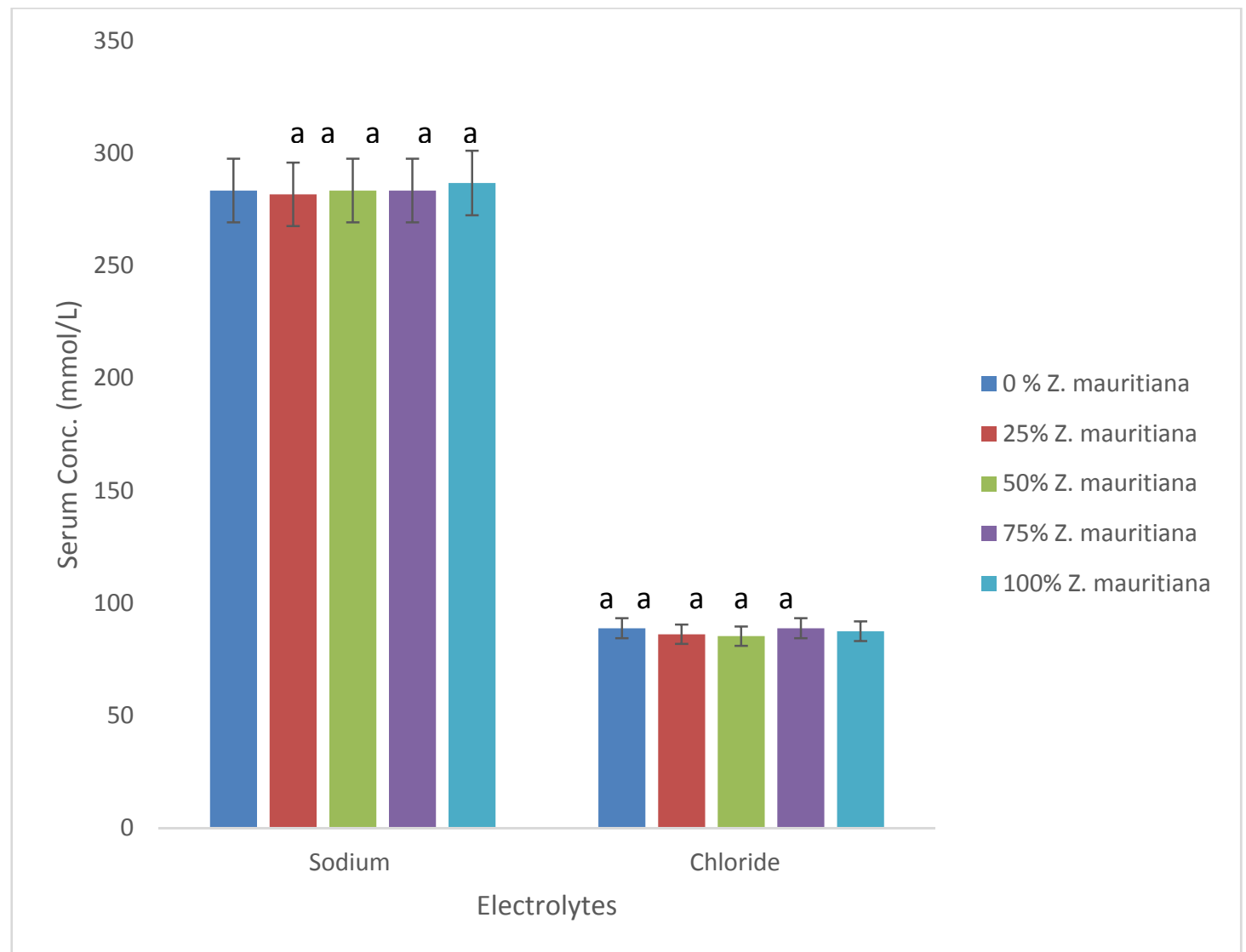

Figure 5. Effect of graded level of Z. mauritiana inclusion as protein source on sodium concentration in rats

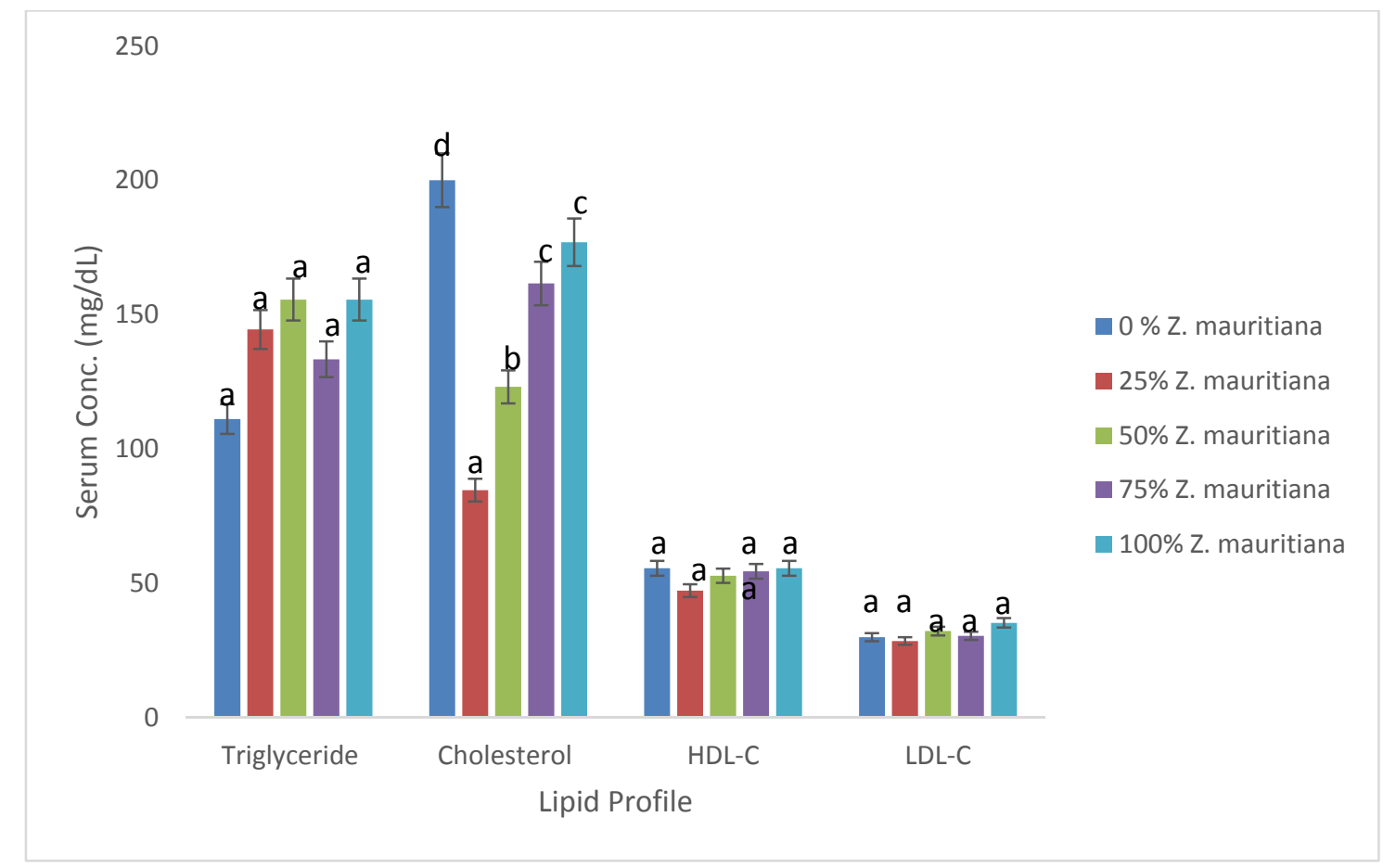

Figure 6. Effect of graded level of $Z$. mauritiana inclusion as protein source on lipid profile in rats 
The serum concentrations of high-density lipoprotein (HDL), low density lipoprotein (LDL) and triglyceride in rats fed $25 \%, 50 \%, 75 \%$ and $100 \%$ Z. mauritiana proteins were not significantly $(p>0.05)$ different from the control values. However, the cholesterol concentrations were significantly $(p<0.05)$ lower in rats fed $25 \%, 50 \%$, $75 \%$ and $100 \%$ Z. mauritiana protein when compared with the control value (figure 6). When compared with the normal control, the concentrations of total proteins were higher in rats fed $25 \%, 50 \%$, and $100 \%$ Z. mauritiana proteins but lower in rats fed $75 \%$ Z. mauritiana proteins. Similarly, bilirubin was higher in rats fed $25 \%$, $75 \%$, and $100 \%$ Z. mauritiana proteins when compared with the control.

\section{Hematology}

The hematological parameters including hemoglobin, packed cell volume, mean cell volume, mean cell hemoglobin, mean cell hemoglobin concentration and red blood cell in rats fed $25 \%, 50 \%, 75 \%$ and $100 \%$ Z. mauritiana feed were not significantly different $(p<0.05)$ when compared with the normal control. The platelet counts were significantly lowered in rats fed $25 \%$, $50 \%, 75 \%$ and $100 \%$ Z. mauritiana feed when compared with the control, while total white blood cell count was higher only in rats fed $100 \% \mathrm{Z}$. mauritiana feed proteins when compared with the control (Table 5).

Hematological parameters of rat fed graded level of Z. mauritiana as protein source

Table 5.

\begin{tabular}{|c|c|c|c|c|c|c|c|c|}
\hline$\%$ & HB & PCV & $\mathrm{MCH}$ & $\mathrm{MCH}$ & MCHC & $R B C$ & $P L T$ & $T W B C$ \\
\hline 0 & $14.55 \pm 0.64^{\mathrm{a}}$ & $43.50 \pm 2.12^{\mathrm{a}}$ & $53.00 \pm 0.00^{\mathrm{a}}$ & $17.00 \pm 1.42^{\mathrm{a}}$ & $31.00 \pm 2.82^{\mathrm{a}}$ & $8.80 \pm 0.42^{a}$ & $467.43 \pm 9.56^{b}$ & $7.32 \pm 0.43^{a}$ \\
\hline 25 & $13.30 \pm 0.42^{\mathrm{a}}$ & $40.00 \pm 0.00^{\mathrm{a}}$ & $55.00 \pm 1.41^{\mathrm{a}}$ & $17.50 \pm 2.12^{\mathrm{a}}$ & $30.00 \pm 2.83^{\mathrm{a}}$ & $7.75 \pm 0.92^{a}$ & $215.50 \pm 12.53^{\mathrm{a}}$ & $8.10 \pm 1.41^{a}$ \\
\hline 50 & $13.75 \pm 1.06^{\mathrm{a}}$ & $41.50 \pm 3.54^{\mathrm{a}}$ & $57.50 \pm 2.12^{\mathrm{a}}$ & $17.00 \pm 1.42^{\mathrm{a}}$ & $28.50 \pm 2.12^{\mathrm{a}}$ & $8.10 \pm 0.00^{\mathrm{a}}$ & $215.00 \pm 73.54^{\mathrm{a}}$ & $7.60 \pm 0.54^{\mathrm{a}}$ \\
\hline 75 & $14.30 \pm 0.42^{\mathrm{a}}$ & $43.50 \pm 2.12^{\mathrm{a}}$ & $58.00 \pm 5.66^{a}$ & $18.50 \pm 0.71^{\mathrm{a}}$ & $31.50 \pm 0.71^{a}$ & $7.70 \pm 0.71^{\mathrm{a}}$ & $286.50 \pm 54.45^{\mathrm{a}}$ & $7.20 \pm 0.69^{a}$ \\
\hline 100 & $14.20 \pm 1.27^{a}$ & $44.50 \pm 3.54^{\mathrm{a}}$ & $59.50 \pm 4.95^{\mathrm{a}}$ & $18.00 \pm 1.41^{\mathrm{a}}$ & $33.00 \pm 4.24^{\mathrm{a}}$ & $7.95 \pm 0.21^{a}$ & $287.00 \pm 15.56^{a}$ & $13.10 \pm 1.42^{b}$ \\
\hline
\end{tabular}

\section{Discussions}

Analysis of hematological parameters can be used to assess the deleterious effects of a test substances on the blood cells and also served as a useful predictor of nutritional and malnutrition status of organism exposed to the test food substances [25], to this end, it was necessary to determine the effect of the $Z$. mauritiana as a protein source on hematological parameters. Consequently, the present study showed that $Z$. mauritiana feed at 25\%, 50\%, $75 \%$ and $100 \%$ proteins did not induce obvious toxic changes in the red blood cells (RBC), haemoglobin $(\mathrm{Hb})$, packed cell volume (PCV), mean corpuscular hemoglobin $(\mathrm{MCH})$, mean cell volume (MCV) and mean corpuscular haemoglobin concentration $(\mathrm{MCHC})$ of rats. The absence of significant changes on these indices may suggest that there were no destruction of matured RBC's and no change in the rate of production of erythrocytes (erythropoiesis[26-27]. It also indicates that the test protein source did not possess toxic substances that can cause an anemic condition in rats. The significant increase in the total WBCs observed in rats fed with Z . mauritiana as $100 \%$ proteins could be attributed to the immunological responses of the animals in response to the stress induced by the components of the Z. mauritiana which stimulate leucopoiesis in the bone marrow. However, this property could be useful in enhancing defense system of animals and will thus increase the animal's capability to fight infection [28].

Alteration in biochemical and hematological parameters has been widely accepted and easily assessable indicator of organs impairment and other detrimental effect of drug or food substance consumed to the body systems [29]. Alanine aminotransferase and aspartate aminotransferase are liver based biochemical enzyme that plays important role in protein metabolism. These enzymes are release to serum at certain concentrations, however, when liver is impaired, high amount of these enzymes find their way into the serum, through leakage [30]. These enzymes therefore, become a valuable tool in clinical diagnosis of pathological damage to liver [31]. Consequently, the serum AST and ALT levels were not increased by feeding rats with $Z$. mauritiana as $25 \%, 50 \%, 75 \%$ and $100 \%$ protein source and this indicated that the activity of the functional integrity of the liver was preserved. These also indicated that the amino acid 
metabolism and energy generation of the animals has not been compromised.

The observed increase in the total proteins, contents in rats fed $100 \%$ Z. mauritiana suggests a compromise of the synthetic ability of the liver. This $100 \%$ Z. mauritiana protein source might have increased the functional activity of the liver by interfering with the equilibrium in the rate of synthesis and destruction, removal or clearance of total proteins from the system of the animals [32]. Such increase in total protein could, however, lead to dehydration which is detrimental to cellular homeostasis [33]. This will negatively affect the metabolic activities of the liver and consequently the health of the animals. However, no significant differences in the serum total proteins, concentrations in rats fed $25 \%, 50 \%$ and $75 \% Z$. mauritiana protein source when compared with the control. This indicates that the activity of the liver was preserved. Albumin is a protein synthesized by the liver and plays a varieties of roles such as translocations of various hormones, minerals, fatty acids and enzymes [34]. Thus commonly used to assess nutritional status and liver integrity [35-36]. In the present study, no feeding related change in albumin levels an indication of adequate nutritional status and preserved liver integrity

The kidneys control the excretion of urea, creatinine and reabsorption of electrolytes into the blood. Defeat in activities of kidney will result in accumulation of electrolytes, urea and creatinine in the biological fluid [37]. The non-significant ( $p>0.05)$ changes in serum concentrations of sodium and chloride suggests that the normal excretion of these electrolytes by the kidney has not been compromised [38]. Urea and creatinine concentrations were also found not to be significantly altered thus suggesting that the functional integrity of kidney has been preserved and thus no renal dysfunction could be attributed to the feeding of rats with Z. mauritiana at $25 \%$, $50 \%, 75 \%$ and $100 \%$ protein source

Total cholesterol (TC), triglyceride (TG), highdensity lipoprotein (HDL) and low-density lipoprotein (LDL) are known as lipid profile and increase concentrations of these parameters suggest an abnormal lipid metabolism and predisposition of the heart to atherosclerosis and its associated coronary heart diseases [39]. Thus, assessment of these lipid profile is crucial in evaluating nutritional adequacy and effect of food substance. Consequently, the lipid profile analysis showed that the mean cholesterol concentrations were significantly $(p<0.05)$ lower in rats fed $Z$. mauritiana at $25 \%, 50 \%, 75 \%$ and $100 \%$ protein source when compared with the control. This is an indication of hypocholesterolemic effect of $Z$. mauritiana. In this study, no such alterations in the HDL-C, LDL-C and triglyceride concentrations were recorded after feeding rats with $Z$. mauritiana at $25 \%, 50 \%, 75 \%$ and $100 \%$ protein source and this supports the non-toxic nature of $Z$. mauritiana.

Body weight gain and internal organ weights are simple but strong and sensitive indices of toxicity after exposure to toxic substances [40]. Interestingly, rats fed $50 \%$ and $100 \% \quad Z$. mauritiana proteins had the highest weight gain of $27.50 \pm 0.00 \mathrm{~g}$ and $28.50 \pm 4.92 \mathrm{~g}$ respectively when compared with the normal control indicating the inherent weight gaining potential of the feed. The observed significant weight gain could have been mediated via appetite stimulatory or other mechanisms. This correlate with the higher feed intake of $157.70 \pm 5.09 \mathrm{~g}, 150.35 \pm 0.71 \mathrm{~g}$ and $145.45 \pm 0.92 \mathrm{~g}$ at $25 \%, 50 \%$ and $100 \% \quad Z$. mauritiana protein source. Changes in the relative organ weight are strong indications of organ enlargement (organomegally, hypertrophy or hyperplasia) or organs constriction (hypotrophy) as a secondary effect that follows biochemical alterations [27, 29]. Fortunately, the organ body weight ratio of rat kidney, lung, and heart compared favorably $(p>0.05)$ with those of the controls and no significant change was observed at $25 \%, 50 \%$ and $75 \%$ Z. mauritiana protein source. However, the liver hypertrophy observed in rats fed $100 \% Z$. mauritiana call for concern Since no major alterations were found in the organ weight, hematological and biochemical parameters. The results of this study have established that feeding of rats with $Z$. mauritiana at $25 \%, 50 \%$, and $75 \%$ has no adverse effect on the functions of the liver, kidney and bone marrow in albino rats.

\section{Conclusions}

Ziziphus mauritiana seed possess good dietary protein quality for optimal growth of rats and does not elicit any adverse effect on haematological and serum biochemical indices of organs integrity thus could be considered a potential and safe source of proteins for proper growth.

\section{References}

1. Umar, I.A., Saidu, Y., Lawal, M., \& Maigandi, S.A. (2010). Biochemical and Haematological Indices of Weanly Albino Rats Fed Millet and Maize Based Complementary Weaning Food. Nigerian Journal of Basic and Applied Science, 18(1),44-49

2. WHO - World Health Organization. (2011). Avaiable from: http://www.who.int/en

3. Addass, P.A., Midau, A., Perez, I.K., \& Magaji, M.Y. (2010).The effect of type and levels of animal protein supplements on the growth rate of rats. 
Agriculture and biology journal of north america, 1(5), 841-844

4. Soetan, K.O., Akinsulie, O.C., Tijani, M.O., \& Olaiya, C.O. (2017). "Studies on Haematology, Serum Chemistry and Histology of Liver and Kidneys of Male Wistar Strain Albino Rats Fed Graded Levels of Raw Pigeon pea (Cajanus cajan) Seeds". EC Nutrition, (8) $3,75-84$

5. Saleh, J. L. Njidda, A. A. Adeniji, AA., \& Lawan G. B. (2014). Haematological and Biochemical Indices of Rabbits Fed Graded Levels Browse Forage (Balanites aegyptiaca) in Semi Arid Environment. Global Journal of Science Frontier Research, 14 (2),2327

6. Thanatcha, R., \& Pranee, A. (2011). Extraction and characterization of mucilage in Ziziphus mauritiana Lam. International Food Resesrch Journal, 18,201-212

7. Huwale, T.D. (1985). "Pollen studies in ziziphus Mauritian cultivars" Annals of Arid zone Journal, 1, 4750

8. Upadhyay, S., Upadhyay, P., Ghosh, A.K., \& Singh, V. (2012). Ziziphus Mauritiana : A Review On Pharmacological Potential Of This Underutilized Plant, International Journal of Current Research and Review, 4(3), 141-144

9. Wadekar, R.E. (2008). Effect of Ziziphus maurtiana leaf extract on phagocytosis by human neutrophills Journal of Pharmacy Research,1. 1-7.

10. Bhatia, A., \& Mishra, T. (2009). Free radical scavenging activity and inhibitory responces of ziziphus maurtiana seed extract on alcohol induced oxidative. An international forum for Evidence Based Practices, 1.: 8 11. Mishra, T., Kullar, N., \& Bhatia, A. (2011). Anticancer potential of Aqueous ethanol seed extract of Ziziphus maurtiana against cancer cell lines and Ehrlich Ascites Carcinoma. Evidence Based Complementary And Aleternative medicines, 1,1-8

12. Dahiru, D., Sini, J.M., \& John, A. (2006). Africa L Antidiarrhoeal activity of Ziziphus maurtiana root extract in rodents. African Journal of Biotechnology, 5,1-10

13. Bhatia, A., \& Mishra, T. (2010). Hypoglycemic activity of Ziziphus maurtiana aqueous ethanol seed extract in alloxan induced diabetic mice. Pharmaceutical biology, 48,604

14. Panchal, S., Panchal, K., Vyas, N., Modi, K., Patel, V., Bharadia, P., \& Pundarikakshudu, K. (2010). Antiulcer Activity of Methanolic Extract of Zmauritiana stem Bark. International Journal of Pharmacognosy and Phytochemical Research, 2, 3, 611

15. Abalaka, M.E., Daniyan, S.Y., \& Mann, A. (2010) Evaluation of the antimicrobial activities of two Ziziphus species. ZmauritianaL and Ziziphus spinachristi L. on some microbial pathogens. African Journal of Pharmacy and Pharmacology, 4, 4,135-139

16. Panomwan, P., Kanlaya, L., Samran, P., Palangpon, K., Apichart, S., Somsak, R., \& Sunit, S. (2011). Antiplasmodial and antimycobacterial cyclopeptide alkaloids from the root of Ziziphus mauritiana. Phytochemistry,72, 909-915

17. Bashir, L., Shittu, O.K., Busari, M.B., Sani, S.,\& Aisha, M.I. (2015).Safety Evaluation of Giant African land Snails (Archachatinamarginata) Haemolymph on Hematological and Biochemical Parameters of Albino
Rats. Journal of Advances in medical and Pharmaceutical Sciences, 3(3),122-130

18. Yusuf, A.A., Lawal, B., Yusuf, M.A., Omonije, Y.O., Adejoke, A.A., Raji, F.H., \& Wenawo, D.L. (2018). Free Radical Scavenging, Antimicrobial Activities and Effect of Sub-Acute Exposure to Nigerian Xylopia Aethiopica Seed Extract On Liver and Kidney Functional Indices of Albino Rat. Iranian Journal of toxicology, 12 (3), 51-58

19. Reitman, S., \& Frankel, S. (1957). A colorimetric method for the determination of serum glutamic oxalacetic and glutamic pyruvic transaminases. American Journal of Clinical Pathology, 28, 56-63.

20. Gornall, A.C., Bardawill, C.J., \& David, M.M. (1949) Determination of serum protein by means of biuret reaction. Journal of Biological Chemistry,177: 751-66.

21. Doumas, B.T., Watson, W.A., \& Biggs, H.G. (1971) Albumin standards and the measurement of serum album with bromocresol green. Clinical Chemistry Act, 31: 87-96.

22. Tietz, N.W. (1995). Clinical guide to laboratory tests. 3rd ed. Philadelphia, PA: WB Saunders Company; 286-8.

23. Friedewald, W.T., Levy, R.I, \& Fredrickson, D.S. (1972) In: Tietz, editor. Determination of LDL cholesterol. New York: Text Book of Clinical Biochemistry;

24. Dacie, J.V., \& Lewis, S.M. (1995). Practical Haematology. 7th Edition. Churchill Livinstone, Edinburg, London. Pp. 12-17.

25. Omodamiro, O.D., \& Nwankwo, C.I. (2013).The effect of voacanga africana leaves extract on serum lipid profile and haematological parameters on albino wistar rats . European Journal of Experimental Biology, 3(3):140-148

26. Lawal, B., Shittu, O.K., Abubakar, A.N., Haruna, G.M., Sani, S., \& Ossai, P.C. (2015) Haematopoetic Effect of Methanol Extract of Nigerian Honey Bee (Apis mellifera) Propolis in Mice. Journal of Coastal Life Medicine, 3(8), 648-651.

27. Berinyuy, E.B., Lawal, B., Olalekan,, A.A., Olalekan, A.A., Yusuf, A.A., Sakpe, S., \& Ossai, P.C. (2015). Hematological Status and Organs/Body-weight Parameters in Wister Rats during Chronic Administration of Cassia occidentalis. International Blood Research \& Reviews, 4(3): 1-7.

28. Lawal, B., Shittu, O.K., Rotimi, A.A., Olalekan, A.A., Kamooru, A.A., \& Ossai, P.C. (2015). Effect of Methanol Extract of Telfairia occcidentalis on Haematological Parameters in Wister Rats. Journal of Medical Sciences, 15 (5): 246-250

29. Shittu, O.K., Lawal, B., Blessing Uchenna, A.B., Haruna, G.M., Abubakar, A.N., \& Berinyuy, E.B. (2015). Alteration in Biochemical Indices Following Chronic Administration of Methanolic Extract of Nigeria Bee Propolis in Wister Rats. Asian Pacific journal of tropical disease, 5(8), 654-657

30. Shittu, O.K., Lawal, B., Abubakar, N.A., Berinyuy, B.E., Busari, M.B., \& Ibrahim, A.O. (2015). Toxicological Implications of Methanol Extract from Nigerian Bee Propolis on Some Selected Rat Tissues. Journal of Pharmaceutical and Biomedical Science. 05(06),499-506. 
31. Lawal, B., Shittu, O.K., Oibiokpa, I.F., Mohammed, H., Umar, S.I., \& Haruna, G.M. (2016). Antimicrobial evaluation, acute and sub-acute toxicity studies of Allium sativum, Journal of Acute Diseases, 5(4): 296-301

32. Yakubu, M.T., Bilbis, L.S,.Lawal, M. \& Akanji, M.A. (2013).Effect of repeated administration of sildenafil citrate on selected enzyme activities of liver \& kidney of male albino rats.Nigerian Journal of Pure \& Applied Sciences, 18, 1395- 1400

33. Yusuf, A.A., Lawal, B., Abubakar, A.N., Berinyuy, E.B., Omonije, Y.O., Umar, S.I., Shebe, M.N., and Alhaji, Y.M. (2018). In-vitro antioxidants, antimicrobial and toxicological evaluation of Nigerian Zingiber officinale. Clinical Phytoscience, 4, 12, 1-8

34. Garcia-Martinez, R., Caraceni, P., Bernardi, M., Gines, P., Arroyo, V., \& Jalan, R. (2013). Albumin:Pathophysiologic basis of its role in the treatment of cirrhosis and its complications. Hepatology,58(5), 1836-1846

35. Bharadwaj, S., Ginoya, S., Tandon, P., Gohel, T. D., Guirguis, J., Vallabh, H., Hanouneh, I. (2016). Malnutrition: Laboratory markers vs nutritional assessment.Gastroenterology Report,4(4), 272-280.

36. Sławomir, L., Monika, L., Jerzy, B., Bolesław, K.,Jacek, Z.K., \& Aneta, L. (2018) The long-term effect of a protein-deficient-diet enriched with vitaminB6 on the blood parameters in unexercised and exercised rats, Food and Agricultural Immunology,29,1, 722-734,

37. Alebachew., M., Yamrot K., Eyasu M., Yonas B., Kelbesa U., \& Mekbeb A. (2014). Toxicological evaluation of methanol leaves extract of Vernonia bipontini Vatke in blood, liver and kidney tissues of mice. African Health Science,14(4): 1012-1024.

38. Umar, S.I., Ndako, M., Jigam, A.A. Adefolalu, S.F., Ibikunle, G.F., \& Lawal, B. (2019). Antiplasmodial, Anti-inflammatory, antinociceptive and safety profile of Maytenus senegalensis root bark extract on hepato-renal integrity in experimental animals. Comparative Clinical athology, https://doi.org/10.1007/s00580-019-02965-4

39. Owoyele, B.V., Oyelowo, OT, Biliaminu, ON Alaran, S.A. Alimi SA, \& Saliu R.S. (2011). Hematological and biochemical studies on Parquetina nigrescens root extract in albino rats. Journal of Applied Pharmaceutical Science, 01 (10), 176-179

40. Adeneye, A.A., Adeyemi O.O., Agbaje E.O., \& Banjo A.A. (2010). Evaluation of The Toxicity And Reversibility Profile Of The Aqueous Seed Extract Of Hunteria Umbellata (K. Schum.) Hallier F. In Rodents. African Journal of Tradititional Complementary Alternative Mediceine, 7(4):350-369. 